\title{
Application of Mobile Technologies for the Formation of Analytical Competence of Future Specialists
}

\author{
https://doi.org/10.3991/ijim.v14i02.11658 \\ Olga V. Galustyan $\left({ }^{\bowtie}\right)$, Alexander P. Smetannikov, Indira G. Kolbaya \\ Southern Federal University, Rostov-on-Don, Russia \\ olga.galustyan@gmail.com \\ Galina S. Palchikova, Denis V. Galigorov \\ The Military Educational and Scientific Center of "The Air Force Academy named after \\ Zhukovsky N.E. and Gagarin Y.A.”, Voronezh, Russia \\ Olga B. Mazkina \\ Voronezh State University, Voronezh, Russia

\begin{abstract}
The article deals with application of mobile technologies for the formation of analytical competence of future specialists. It discusses the concepts of mobile learning and mobile technologies. Advantages of using mobile technologies within the learning process are presented. The use of mobile learning is one of the most effective and affordable ways of formation of students' analytical competence. Managing, strategic, informational, reflexive components within the structure of analytical competence are revealed in the article. The results of experimental work of formation of analytical competence of future specialists by means of mobile learning technologies are presented. The authors conclude that formation analytical competence of future specialists using mobile devices expands the conventional framework by using the capabilities of mobile platforms and expands the learning environment.
\end{abstract}

Keywords-Mobile technologies, mobile learning, analytical competence, ICT tools, future specialists

\section{Introduction}

Social, economic and technical changes in the modern world, needs of information society and digital economy predetermined high importance of formation of analytical competence of a future specialist by means of mobile learning $[3,13,14]$. Education has determined tendency of introduction of software, computer and information technologies, minimization of circulation of printed documents, digitalization. Qualification of contemporary specialist should be characterized by the development of analytical competence which is necessary for the analysis of informational flows within his / her professional activity. All these requires updating of the content of training of future specialists within new conditions $[1,6,9,11]$. 


\section{Methodology}

Mobile learning is becoming a part of higher education at the age of high technologies. Modern period of development in the field of ICT provides simple and affordable ways for obtaining information. Sharing of information is an integral part of each person's life nowadays. Such devices as phones, tablet computers, smartphones become the basis of digital life of everyone. Electronic devices perform more and more complex tasks and process an enormous flow of information [12, 15, 17].

Mobile learning technologies are closely connected with the educational mobility as the students have an opportunity to participate at educational events without restrictions in time and space. Opportunity to study anywhere and at any time is common tendency of human life within the information society [22, 23].

There are a lot of interpretations of the concept of "mobile learning", but the most common is that such learning doesn't need connection to the cable network. Mobile learning involves availability of mobile tools regardless of time and place using special software $[2,16,18]$. Thus, mobile learning is a form of learning organization based on the use of mobile ICT and wireless communications. Mobile learning means a continuous access to the educational resources, possibility of interaction with teachers and classmates. Mobile learning is also is a kind of distance learning using ICT tools $[5,10]$.

Nowadays mobile devices are available for almost everyone from 6 to 60 years of age. Consequently, mobile applications are always relevant. Most of the users do not use all the opportunities of their devices; do not reveal the potential invested in them. This means that the students are poorly aware of the possibilities offered by the smartphones and other smart additions. Most of the students are familiar only with the gaming side of mobile life. At the same time, there is a little information concerning the use of mobile applications, smartphones within the educational purposes $[4,19]$.

Learning disciplines using mobile applications is a relatively new way that is gaining popularity. It is quite logical to use mobile applications as auxiliary elements within the educational system.

Mobile application is software developed for use on smartphones, tablet computers and other mobile devices. The basic part of mobile applications is provided and installed on the device itself or can be downloaded for free or for a fee from online application stores, such as AppStore, BlackBerry App World, GooglePlay, 1mobile market, Windows Phone Store, Yandex.store and the others.

The original purpose of such software was to check email quickly and conveniently, but significant demanded to lead to an increase in purposes in various fields.

Students prefer mobile technologies and use them regularly in their personal life. Therefore, it is not surprising that it won't be difficult to apply mobile devices for learning for today's young people. There is a tendency to use mobile devices for studying as: 
- Communicator (exchanging of information between each other)

- Camera (photographing texts, etc.)

- Dictaphone (recordings voice of a lecturer)

- Mobile browser (access to sites)

- Walkman (listening to the lectures)

- Stopwatch (conducting experiments)

- Translator (translation of foreign texts), etc. [7, 8, 27]

Mobile learning becomes real in the successful implementation of educational activities. Scientists $[25,26,28]$ identify such advantages of mobile learning as:

- Mobility

- Permanent education

- Personalization of learning

- Improving the quality of communication

- Providing a range of dialogue capabilities

- Offline learning and sharing of information

One of the benefits of using mobile technologies within the learning process is that students have access to any information. Choosing among the vast number of available sources of information opens up to the students unlimited learning opportunities, which give them freedom and independence. Mobile learning applies innovative technologies with the help of which changes occur in the teaching process. Such modern services as social networks, cloud storages, media hosting sites are used for delivery of certain kind of information. Many teachers use social networks for spreading useful information there [20, 24, 29].

It becomes inevitable to search for new and appropriate ways of presenting information in order to compensate for educational needs of a modern person. But this will be possible only when all teachers will be active users of information and communication technologies (ICT).

\section{$3 \quad$ Materials and Methods}

Experimental work took place in 2018-2019 at universities (Southern Federal University, Rostov-on-Don and Military Educational and Scientific Center of "The Air Force Academy named after Zhukovsky N.E. and Gagarin Y.A.", Voronezh). 237 students and cadets participated in the study. Respondents were from 19 to 21 years of age. Experimental group consisted of 119 participants. Control group included 118 participants.

Formation of analytical competence among the participants of the experiment was carried out within the process of learning activities of the study the disciplines "Fundamentals of Management" and "Management Theory". Special course "Analytical Competence of the Future Specialist" was also introduced. The content of the course revealed theoretical foundations of analytical competence, its structure, functions and mechanisms. Organizational and managerial situations, reflexive 
practical tasks were presented. Special course included tasks for self-regulated learning, questions for self-testing and creative tasks. Tasks for consolidating theoretical knowledge, for the formation of analytical competence skills were solved within this course.

We used the following mobile learning tools during the experimental work:

- ISpringCloud storage for publishing mobile educational resources

- Developed environment of mobile multi-format educational materials based on iSpring products

- Mirapolis Virtual Room system software for participation in webinars

- Development of educational materials on mobile devices in office applications

- The advantages of mobile applications

- Intuitive interface

- Convenient library of educational materials

- Instant access to selected materials

- Offline viewing of lectures

This software had a wide range of capabilities from creating multimedia to interactive courses which were designed to be used not only for personal computers but also for mobile devices. These programs allowed the students to view and to listen to the videos and lectures on their smartphones, tablets an unlimited number of times anytime and anywhere. After the course students had an opportunity to evaluate their knowledge making a test.

\section{$4 \quad$ Results}

Initial study was conducted to identify the initial level of analytical competence in experimental and control groups at the beginning of courses. We define analytical competence as an integral property of a person, characterizing his / her aspiration and ability (readiness) to realize his / her potential (knowledge, skills, experience, personal qualities, etc.) for successful socialization and adaptation in professional activity. We have identified managing, strategic, informational, reflexive components within the structure of analytical competence.

Managing component is an integrative characteristic of a person, which is expressed in ability to plan work, to coordinate goals, responsibilities and working agreements; ability to make objective management decisions considering quantitative and qualitative analysis of alternative opportunities.

Strategic component is willingness and ability of a person to define goals of collaborative activities, to offer his / her own solution of the problem and to discuss it, to work out a decision in collaborative discussion; ability to define tasks, resources and timelines in order to achieve goals.

Informational component is revealed in skills of using the potential of informational resources provided by means of information and communication and mobile technologies. 
Reflexive component includes ability to improve teamwork, to analyze and to evaluate collaborative activities of the group, activity of each participant, his / her own activity.

The data obtained were summarized and converted to percentage. The empirical data were quantitatively processed and analyzed at a qualitative level. Dynamics of step-by-step development of analytical competence was established and the obtained data are revealed in Table 1 and Table 2.

Table 1. The results of the assessment of the level of analytical competence in the experimental and control groups before the experimental work

\begin{tabular}{|l|c|c|c|c|c|c|}
\hline \multirow{2}{*}{$\begin{array}{c}\text { Analytical } \\
\text { competence }\end{array}$} & \multicolumn{3}{|c|}{ Experimental group } & \multicolumn{3}{c|}{ Control group } \\
\cline { 2 - 7 } & Low level, \% & $\begin{array}{c}\text { Middle level, } \\
\text { \% }\end{array}$ & $\begin{array}{c}\text { High level, } \\
\text { \% }\end{array}$ & Low level, \% & $\begin{array}{c}\text { Middle level, } \\
\text { \% }\end{array}$ & $\begin{array}{c}\text { High level, } \\
\%\end{array}$ \\
\hline $\begin{array}{l}\text { Managing } \\
\text { component }\end{array}$ & 40,8 & 38,3 & 20,9 & 39,8 & 38,6 & 21,6 \\
\hline Strategic component & 55,4 & 28,7 & 15,9 & 37,2 & 39,8 & 23,0 \\
\hline $\begin{array}{l}\text { Informational } \\
\text { component }\end{array}$ & 42,7 & 33,5 & 23,8 & 41,9 & 30,3 & 27,8 \\
\hline Reflexive component & 56,6 & 29,2 & 14,2 & 44,1 & 34,5 & 21,4 \\
\hline
\end{tabular}

Table 2. The results of the assessment of the level of analytical competence in the experimental and control groups after the experimental work

\begin{tabular}{|c|c|c|c|c|c|c|}
\hline \multirow{2}{*}{$\begin{array}{l}\text { Analytical } \\
\text { competence }\end{array}$} & \multicolumn{3}{|c|}{ Experimental group } & \multicolumn{3}{|c|}{ Control group } \\
\hline & Low level, \% & \begin{tabular}{|c|} 
Middle level, \\
$\%$
\end{tabular} & $\begin{array}{c}\text { High level, } \\
\%\end{array}$ & Low level, \% & \begin{tabular}{|} 
Middle level, \\
$\%$
\end{tabular} & $\begin{array}{c}\text { High level, } \\
\%\end{array}$ \\
\hline $\begin{array}{l}\text { Managing } \\
\text { component }\end{array}$ & 12,9 & 37,6 & 49,5 & 41,5 & 38,6 & 19,9 \\
\hline Strategic component & 8,1 & 26,8 & 65,1 & 34,6 & 43,1 & 22,3 \\
\hline $\begin{array}{l}\text { Informational } \\
\text { component }\end{array}$ & 8,8 & 23,4 & 67,8 & 33,1 & 38,2 & 28,7 \\
\hline Reflexive component & 5,6 & 27,9 & 66,5 & 42,8 & 36,9 & 20,3 \\
\hline
\end{tabular}

Comparative analysis of the results of input and final diagnostics of the formation of analytical competence in the control and experimental groups showed a significant dynamic of the development of analytical competence in experimental groups, which indicates the effectiveness of the experimental work.

\section{Conclusion}

Modernization and updating of teaching methods are necessary for contemporary educational process. The use of mobile learning is one of the most effective and affordable ways of formation of students' analytical competence. Moreover, mobile learning makes education more attractive for future specialists.

Thus, the proposed approach of formation analytical competence of future specialists using mobile devices expands the conventional framework by using the capabilities of mobile platforms. It expands the learning environment and goes 
beyond it. The experience of using mobile learning has shown its feasibility and effectiveness in modern implementation of educational practice.

\section{References}

[1] Amdani, D., Sinulingga, S., Absah, Y., \& Muda, I. (2019). The effect of competence and organizational culture on employee performance of Ganesha Medan Polytechnic. International Journal of Scientific and Technology Research, 8(4), 155-159.

[2] Ben Said, A., Erradi, A., Neiat, A. G., \& Bouguettaya, A. (2019). A deep learning spatiotemporal prediction framework for mobile crowdsourced services. Mobile Networks and Applications, 24(3), 1120-1133. https://doi.org/10.1007/s11036-018-1105-0

[3] Bubnov, Y. A., Gaidar, K. M., Fedorov, V. A., Berezhnaya, I. F., \& Galustyan, O. V. (2018). Organization of the training process based on modular and rating technology at higher educational institution. Espacios, 39(25)

[4] Burden, K., Kearney, M., Schuck, S., \& Hall, T. (2019). Investigating the use of innovative mobile pedagogies for school-aged students: A systematic literature review. Computers and Education, 138, 83-100. https://doi.org/10.1016/j.compedu.2019.04.008

[5] Chattopadhyay, A., Blaszczyszyn, B., \& Altman, E. (2019). Location aware opportunistic bandwidth sharing between static and mobile users with stochastic learning in cellular networks. IEEE Transactions on Mobile Computing, 18(8), 1802-1815. https://doi.org/10. $\underline{1109 / \mathrm{tmc} .2018 .2867037}$

[6] De Vasconcellos, S. L., Garrido, I. L., \& Parente, R. C. (2019). Organizational creativity as a crucial resource for building international business competence. International Business Review, 28(3), 438-449. https://doi.org/10.1016/j.ibusrev.2018.11.003

[7] Dey, S., Ye, Q., \& Sampalli, S. (2019). A machine learning based intrusion detection scheme for data fusion in mobile clouds involving heterogeneous client networks. Information Fusion, 49, 205-215. https://doi.org/10.1016/j.inffus.2019.01.002

[8] Dourado, C. M. J. M., da Silva, S. P. P., da Nóbrega, R. V. M., Barros, A. C. S., Sangaiah, A. K., Rebouças Filho, P. P., \& de Albuquerque, V. H. C. (2019). A new approach for mobile robot localization based on an online IoT system. Future Generation Computer Systems, 100, 859-881. https://doi.org/10.1016/j.future.2019.05.074

[9] Dumas, A. (2019). From communicational skills to regulation of emotions at work: Organizational rationalizations, which highlights the study of health prevention devices in company. [Des compÉtences communicationnelles Ç la rÉgulation des Émotions au travail: Les rationalisations organisationnelles que rÉvÈle l'Étude des dispositifs de prÉvention de la santÉ en entreprise] Communication Et Management, 16(1), 65-77. https ://doi.org/10.3917/comma.161.0065

[10] Fabian, K., \& Topping, K. J. (2019). Putting "mobile" into mathematics: Results of a randomised controlled trial. Contemporary Educational Psychology, 59 https://doi.org/10. 1016/i.cedpsych.2019.101783

[11] Flentje, M., Böhmelt, D., Sieg, L., \& Eismann, H. (2019). Instructors for on-the-job training of advanced paramedics - definition of competencies and development of a quality management tool for a "high responsibility organization". [Praxisanleiter in der notfallsanitäterausbildung - definition von kompetenzen und eines qualitätssicherungstools für eine, high responsibility organisation"] GMS Journal for Medical Education, 36(1) doi: $10.3205 / \mathrm{zma} 001216$ 
[12] Galustyan, O. V., Borovikova, Y. V., Polivaeva, N. P., Kodirov, B. R., \& Zhirkova, G. P. (2019). E-learning within the field of andragogy. International Journal of Emerging Technologies in Learning, 14(9), 148-156. https://doi.org/10.3991/ijet.v14i09.10020

[13] Galustyan, O. V., Gaidar, K. M., Aleshina, S. A., Ksenofontova, A. N., \& Ledeneva, A. V. (2018). Development of group subjectivity of pupils within collaborative activities. TEM Journal, 7(4), 854-858. doi:10.18421/TEM74-25

[14] Galustyan, O. V., Lazukin, V. F., Petelin, A. S., \& Ostapenko, V. S. (2018). Diagnostic Activity of Teachers at High School. Revista Espacios, Vol. 39(N 10). Retrieved from http http://www.revistaespacios.com/a18v39n10/18391024.html

[15] Galustyan, O. V., Meshcheryakova, E. I., Larina, T. V., Bakleneva, S. A., \& Krivotulova, E. V. (2018). Self-regulated learning of students at university. Espacios, 39(23)

[16] Herry Setyawan, W., Budiman, A., Septa Wihara, D., Setyarini, T., Nurdyansyah, Rahim, R., \& Barid Nizarudin Wajdi, M. (2019). The effect of an android-based application on Tmobile learning model to improve students' listening competence. Paper presented at the Journal of Physics: Conference Series, , 1175(1) https://doi.org/10.1088/1742-6596/1175/ $1 / 012217$

[17] Huang, Y., Yan, A., \& Smith, R. (2019). Methodology for the development of knowledge management on organizational performance based on employees' professional competence. Revista De Cercetare Si Interventie Sociala, 64, 85-96. https://doi.org/10.337 $\underline{88 / \text { rcis. } 64.7}$

[18] Huizenga, J., Admiraal, W., Dam, G. T., \& Voogt, J. (2019). Mobile game-based learning in secondary education: Students' immersion, game activities, team performance and learning outcomes. Computers in Human Behavior, 99, 137-143. https://doi.org/10.1016/j. $\underline{\text { chb.2019.05.020 }}$

[19] Innocenti, E. D., Geronazzo, M., Vescovi, D., Nordahl, R., Serafin, S., Ludovico, L. A., \& Avanzini, F. (2019). Mobile virtual reality for musical genre learning in primary education. Computers and Education, 139, 102-117. https://doi.org/10.1016/j.compedu.2019.04.010

[20] Jagannath, J., Polosky, N., Jagannath, A., Restuccia, F., \& Melodia, T. (2019). Machine learning for wireless communications in the internet of things: A comprehensive survey. Ad Hoc Networks, 93 https://doi.org/10.1016/j.adhoc.2019.101913

[21] Kanjo, E., Younis, E. M. G., \& Ang, C. S. (2019). Deep learning analysis of mobile physiological, environmental and location sensor data for emotion detection. Information Fusion, 49, 46-56. https://doi.org/10.1016/j.inffus.2018.09.001

[22] Kravchenko E.V., Galustyan O.V, Kovtunenko L.V., \& Kolosova L.A. (2018). Pedagogical Practice of Students. Revista Espacios, Vol. 39 (N 17). Retrieved from http://www.revistaespacios.com/a18v39n17/18391731.html

[23] Li, M., Gao, S., Lu, F., \& Zhang, H. (2019). Reconstruction of human movement trajectories from large-scale low-frequency mobile phone data. Computers, Environment and Urban Systems, 77 https://doi.org/10.1016/j.compenvurbsys.2019.101346

[24] Nawrocki, P., Sniezynski, B., \& Slojewski, H. (2019). Adaptable mobile cloud computing environment with code transfer based on machine learning. Pervasive and Mobile Computing, 57, 49-63. https://doi.org/10.1016/j.pmcj.2019.05.001

[25] Pérez-Paredes, P., Ordoñana Guillamón, C., Van de Vyver, J., Meurice, A., Aguado Jiménez, P., Conole, G., \& Sánchez Hernández, P. (2019). Mobile data-driven language learning: Affordances and learners' perception. System, 84, 145-159. https://doi.org/10.10 16/j.system.2019.06.009

[26] Sung, Y., Lee, H., Yang, J., \& Chang, K. (2019). The quality of experimental designs in mobile learning research: A systemic review and self-improvement tool. Educational Research Review, 28 https://doi.org/10.1016/j.edurev.2019.05.001 
[27] Tyrer, C. (2019). Beyond social chitchat? Analysing the social practice of a mobile messaging service on a higher education teacher development course. International Journal of Educational Technology in Higher Education, 16(1) https://doi.org/10.1186/s41239-01 9-0143-4

[28] Uz Bilgin, C., \& Tokel, S. T. (2019). Facilitating contextual vocabulary learning in a mobile-supported situated learning environment. Journal of Educational Computing Research, 57(4), 930-953. https://doi.org/10.1177/0735633118779397

[29] Wang, N., Zhao, X., Zhao, P., Zhang, Y., Zou, Z., \& Ou, J. (2019). Automatic damage detection of historic masonry buildings based on mobile deep learning. Automation in Construction, 103, 53-66. https://doi.org/10.1016/j.autcon.2019.03.003

\section{$7 \quad$ Authors}

Olga V. Galustyan is Professor of the Department of Education and Pedagogical Sciences of Southern Federal University, Rostov-on-Don, Russia.

Alexander P. Smetannikov is Postgraduate of the Department of Education and Pedagogical Sciences of Southern Federal University, Rostov-on-Don, Russia.

Indira G. Kolbaya is Postgraduate of the Department of Education and Pedagogical Sciences of Southern Federal University, Rostov-on-Don, Russia.

Galina S. Palchikova is Lecturer of The Military Educational and Scientific Center of "The Air Force Academy named after Zhukovsky N.E. and Gagarin Y.A.", Voronezh, Russia.

Denis V. Galigorov is Officer-lecturer of The Military Educational and Scientific Center of "The Air Force Academy named after Zhukovsky N.E. and Gagarin Y.A.", Voronezh, Russia.

Olga B. Mazkina is Lecturer of Department of Pedagogy and Pedagogical Psychology of Voronezh State University, Voronezh, Russia.

Article submitted 2019-09-11. Resubmitted 2019-10-15. Final acceptance 2019-10-15. Final version published as submitted by the authors. 